УАК 378.046-021.64/.68(497.115)"2009/...” 378.014.5(497.115)"2009/..."

doi: $10.5937 /$ bastina30-29148

Горан Б. ААЗИК ${ }^{*}$ (1972)

Оригинални научни раА

Универзитет у Приштини

Филозофски факултет Косовска Митровица

Иіор Р. БУРИЋ ${ }^{* *}(1975)$

Универзитет у Приштини

Фимозофски факултет Косовска Митровица

\title{
РАЗВОЈ ТЕМПУС ПРОГРАМА НА УНИВЕРЗИТЕТУ У ПРИШТИНИ СА ПРИВРЕМЕНИМ СЕАИШТЕМ У КОСОВСКОЈ МИТРОВИЦИ
}

\begin{abstract}
$A \bar{u} c \bar{u} р а \kappa \bar{u}:$ Процеси реформе и модернизације високог образовања у Србији инцирани су свеобухватним пројектом „Европа знања“ који је у себи обухватио Бомоњску и Аисабонску декларацију са цињем придруживања земаља Западног Балкана јеАинственом европском простору за високо образовање. Аоношењем Закона о високом образовању 2005. године ови процеси су добили правну основу у Србији, па је овим законом регулисано спровођење принципа обе декларације, Аок је Темпус (Пан-европски програм мобилности за универзитетске студије) као програм Европске уније за реформу и модернизацију високог образовања додатно Аопринео интернационализацији високошколских институција у Србији и усклађивању њихових курикулума са највишим европским образовним стандардима. Овај раА Ааје осврт на развој Темпус програма на Универзитету у Приштини са привременим седиштем у Косовској Митровици оА 2009. године када је Универзитет по први пут аплицирао за ову врсту донације, па све до његовог званичног затварања и завршетка имплементације свих његових пројеката у којима је Универзитет учествовао.
\end{abstract}

Кьучне речи: Темпус, реформа, модернизација, високо образовање.

\section{УBOA}

ЈеАан оА најзначајнијих и најеминентнијих образовних програма Европске уније којим се мери степен интернационализације и квалитет јеАне високошколске институције у Европи је свакако Темпус програм. Овај програм

\footnotetext{
* Аокторана, goranlazicus@gmail.com

** ВанреАни професор, igor.djuric@pr.ac.rs
} 
је значајно Аопринео реформи високошколских институција у Европи, али и у земьама Западног Балкана, међу којима Србија заузима заслужно прво место по броју Аонација које је Аобила за велики број различитих пројеката који су имали за циь унапређење раАа високошколских институција, реформу наставних планова и програма, повезивање академије са тржиштем рада и сарадњу са неакадемским партнерима који су својом експертизом значајно допринели побољшању компетенција и вештина будућих стручњака.

Темпус је као највећи финансијски инструмент за паневеропску мобилност за универзитетске студије заживео на просторима ЗапаАног Балкана у период оА 1991. Ао 2007. гоАине и финансиран је из ИПА (Инструмент уа преАприступну помоћ) фондова. Различите земье ЗапаАног Балкана су се овом програму прикьучияе у складу са реформских процесима које су спроводиле у својим земьама према принципима Болоњске декларације. Србија учествује у Темпус програму оА 2001. године, па све Ао краја 2013. године са укупно 187 пројеката, што је ставьа на прво место по броју Темпус пројеката у односу на остале земье Западног Балкана.

Универзитет у Приштини са привременим сеАиштем у Косовској Митровици је до сада спровео седам (7) Темпус пројеката. Сви ови пројекти су били трогодишњи и имали су велики утицај на реформу саме високошколске институције и оАређеног броја студијских програма, као и на побоьшање сарадње са тржиштем рада.

$\mathrm{O}_{\mathrm{A}}$ 2010. године, Универзитет активно учествује у разАичитим програмима Европске уније који подстичу реформу и модернизацију ове високошколске установе са различитим мокалним, регионалним и међународним високошколским институцијама и неакадемским партнерима (мала и среАња предузећа, агенције, невладине организације).

Темпус је као програм подржао реформу наставних планова и програма, управљачке реформе на високошколским институцијама и сарадњу између високошколских институција и Аруштвених партнера. Са отварањем Темпус канцеларије у Косовској Митровици новембра 2008. године, универзитет је након детаљне припреме успео Аа се прикьучи Темпусу у посмеАњој четвртој фази овог програма у оквиру трећег позива за пројекте у којем је Аобио Ава трогодишња пројекта - PIQAS и SEEPALS. 
Табема 1. Темпус пројекти на Универзитету у Приштини са привременим сеАиштем у Косовској Митровици

\begin{tabular}{|c|c|c|c|}
\hline $\begin{array}{l}\text { Референтни } \\
\text { број пројекта }\end{array}$ & Име пројекта & $\begin{array}{l}\text { Координатор } \\
\text { пројекта }\end{array}$ & $\begin{array}{c}\text { Интернет страна } \\
\text { пројекта }\end{array}$ \\
\hline $\begin{array}{c}\text { 511350-TEMPUS- } \\
\text { 1-2010-1-XK- } \\
\text { TEMPUS-JPGR }\end{array}$ & $\begin{array}{c}\text { PIQAS - Partnership } \\
\text { in Quality Assurance } \\
\text { Standards Implemen- } \\
\text { tation }\end{array}$ & $\begin{array}{l}\text { Универзитет у При- } \\
\text { штини са привреме- } \\
\text { ним седиштем у Ко- } \\
\text { совској Митровици }\end{array}$ & www.piqas.pr.ac.rs \\
\hline $\begin{array}{c}\text { 511116-TEMPUS- } \\
\text { 1-2010-1-XM- } \\
\text { TEMPUS-JPCR }\end{array}$ & $\begin{array}{l}\text { SEEPALS - South } \\
\text { East Europe Project } \\
\text { for the Advancement } \\
\text { of Language Studies }\end{array}$ & $\begin{array}{c}\text { Универзитет Црне } \\
\text { Горе }\end{array}$ & $\begin{array}{c}\text { http://www.erasmus- } \\
\text { plus.ac.me/?tempus- } \\
\text { projekat=south-east- } \\
\text { europe-project-for-the- } \\
\text { advancement-of-language- } \\
\text { studies\&lang=en }\end{array}$ \\
\hline $\begin{array}{l}\text { 517117-TEM- } \\
\text { PUS-1-2011-1- IE- } \\
\text { TEMPUS-JHES }\end{array}$ & $\begin{array}{l}\text { RINGIDEA - De- } \\
\text { veloping information } \\
\text { literacy for long life } \\
\text { learning and knowl- } \\
\text { edge economy in } \\
\text { Western Balkans } \\
\text { countries }\end{array}$ & $\begin{array}{c}\text { Аимерик Институт за } \\
\text { технологију }\end{array}$ & http://www.ringidea.org/ \\
\hline $\begin{array}{c}\text { 517098-TEMPUS- } \\
\text { 1-2011-1-RS- } \\
\text { TEMPUS-JPCR }\end{array}$ & $\begin{array}{l}\text { InMusWB - Introduc- } \\
\text { ing interdisciplinary } \\
\text { in music studies in } \\
\text { the Western Balkans } \\
\text { in line with European } \\
\text { perspective }\end{array}$ & $\begin{array}{c}\text { Универзитет Умет- } \\
\text { ности у БеограАу }\end{array}$ & $\begin{array}{c}\text { https://www.arts.bg.ac.rs/ } \\
\text { en/international/cooper- } \\
\text { ation-in-eu-programmes/ } \\
\text { other-programmes/tem- } \\
\text { pus/ }\end{array}$ \\
\hline $\begin{array}{c}\text { 530266-TEMPUS- } \\
\text { 1-2012-1-XK- } \\
\text { TEMPUS-JPCR }\end{array}$ & $\begin{array}{l}\text { BLATT - Blended } \\
\text { learning: Advanced } \\
\text { teacher training }\end{array}$ & $\begin{array}{l}\text { Универзитет у При- } \\
\text { штини са привреме- } \\
\text { ним сеАиштем у Ко- } \\
\text { совској Митровици }\end{array}$ & $\begin{array}{l}\text { https://issuu.com/tem- } \\
\text { pus_blatt/docs/tempus_ } \\
\text { blatt_project_summary }\end{array}$ \\
\hline $\begin{array}{c}\text { 530440-TEMPUS- } \\
\text { 1-2012-1-XM- } \\
\text { TEMPUS-JPCR }\end{array}$ & $\begin{array}{l}\text { RESARCH - Re- } \\
\text { structuring of study } \\
\text { programme in archi- } \\
\text { tecture to long-cycle } \\
\text { integrated master in } \\
\text { line with EU standards }\end{array}$ & $\begin{array}{c}\text { Универзитет Црне } \\
\text { Горе }\end{array}$ & $\begin{array}{c}\text { http://www.erasmus- } \\
\text { plus.ac.me/?tempus- } \\
\text { projekat=restructuring- } \\
\text { of-study-programme- } \\
\text { in-architecture-to-long- } \\
\text { cycle-integrated-master- } \\
\text { in-line-with-eu-standards- } \\
\text { resarch\&lang=en }\end{array}$ \\
\hline $\begin{array}{c}\text { 530379-TEMPUS- } \\
\text { 1-2012-1-LV- } \\
\text { TEMPUS-JPCR }\end{array}$ & $\begin{array}{c}\text { ENERGY - Devel- } \\
\text { opment of training } \\
\text { network for improving } \\
\text { education in Energy } \\
\text { efficiency }\end{array}$ & $\begin{array}{c}\text { Технички Универзи- } \\
\text { тет у Риги }\end{array}$ & https://e-energy.rtu.lv/ \\
\hline
\end{tabular}

Извор: Универзитету у Приштини са привременим седиштем у Косовској Митровици (www.pr.ac.rs) 


\section{1. ПАРТНЕРСТВО У ИМПАЕМЕНТАЦИЈИ СТАНААРАА ЗА ОБЕЗБЕЂЕЊЕ КВАЯИТЕТА (PARTNERSHIP IN QUALITY ASSURANCE STANDARDS IMPELMENTATION $)^{1}$}

Универзитет је у оквиру свог првог Темпус пројекта, поА називом PIQAS, који је реализовао као координатор уз стручну помоћ Јагелонског универзитета у Кракову, Пољска, Аинеус универзитета у Калмару и Ваксју, ШвеАска, и $\Lambda$ Сапиенца универзитета у Риму, Италија, установио успешан развојни система обезбеђења квалитета, према стандардима Аефинисаним у Приручнику комисије за акредитацију и обезбеђење квалитета Републике Србије, као и према препорукама Приручника за стандарде и смернице за обезбеђења квалитета европског простора за високо образовање. На овај начин, али и кроз остале Темпус пројекте, Универзитет је оснажио сопствену умогу као пружаоца ускуга у области високог образовања и допринео је развоју и унапређењу високог образовања на северу Косова.

Највеће Аостигнуће PIQAS пројекта је у подстицање реформског процеса у пољу обезбеђења квалитета на Универзитету у Приштини са привременим сеАиштем у Косовској Митровици, који су Аопринели његовој конвергенцији ка јединствном простору за високо образовање у Европи, увођењем нове стратешке политике и процеАура у области обезбеђења квамитета којим је такође оснажен будући институционални развој.

Чланови тима који су имплементирали PIQAS пројекат, Канцекарије за обезбеђења квалитета и Комисија за обезбеђење и унапређење квалитета су написали и усвојили нову Статегију обезбеђења квалитета, а уз подршку страних пројектних партнера. Стратегија обезбеђења квалитета усвојена је оА стране Сената Универзитета. Стратегија је дефинисала основне обмасти обезбеђења квалитета за период оА 2013. Ао 2018. године. Финална верзија овог документа је усвојена 13. јула 2013. године, а усклађена је са најновијим уредбама Закона за високо образовање и правним актима који се тичу обезбеђења квалитета у високом образовању Републике Србије. Стратегија такође истиче традиционалне циљеве Универзитета и факултета у његовом саставу у остваривању образовних стандарда и квалитета у раду, као и оданост вредностима и принципима европског универзитетског образовања, узимајући у обзир стандарде и смернице обезбеђења квалитета европског простора за високо образовање. Стратегија подржава и подстиче Ааљи развој институционалног система обезбеђења квалитета који ће омогућити стално праћење, евалуацију и унапређење квалитета у свим научним областима. Након усвајања Стратегије обезбеђења квалитета нареАни корак био је израда и усвајање Акционог плана за имплементацију Стратегије обезбеђења квалитета за период 2013. Ао 2015. године. Акционим планом

1 Темпус пројекат број: 511350-TEMPUS-1-2010-1-XK-TEMPUS-JPGR 
предвиђају се поступци и мере за све области обезбеђења квалитета, субјекти који би требало Аа спроведу поступке и мере, као и оквирни рокови за њихово спровођење.

Оснивање универзитетске канцеларије за обезбеђење квалитета и Канцеларија за обезбеђење квалитета на свим факултетима Универзитета су веома значајни резултати овог Темпус пројекта. Особье задужено за обезбеђење квалитета на нивоу факултета, као и на нивоу Универзитета је изабрано на основу искуства стечених у већ спровеАеним реформским процесима на Универзитету, а у склаАу са Болоњском декларацијом. Канцеларија за обезбеђење квалитета обавьа административне, организационе, техничке и експертске активности које се тичу имплементације и управьења системом обезбеђења квалитета на Универзитету. Заједно са Комисијом за обезбеђење и промоцију квалитета, Канцемарија је задужена да осмисли систем обезбеђења квалитета на Универзитету. Факултетске канцемарије су учествоваяе и у процесу интерне евалуације И изради извештаја о самовреАновању, укьучујући у процес и администрацију и секретаријате факулета. Након спроводеног процеса евалуације, канцекарије су израдиле извештаје и препоруке. Периодичне евалуације су успешно спроведене уз активно учешће академског, административног особња и студената који су заједнички утицали на планирање будућег развоја универзитета.

ОАржано је шест панел састанака у периоду оА 2012. Ао 2013. године. Панели су оАржани оА стране различитих група које су се састојале оА акаАемског и неакадемског особња и студената. Као резултат ових састанка и периодичних надзора, настале су промене у Правилнику за обезбеђење квамитетана на Универзитету.

Студенти су били активно укьучени у све активности новоформираних тела за обезбеђење квалитета која укьучују Комисију за обезбеђење и промоцију квалитета (3 оА 14 чланова су студенти) и Канцеларија за обезбеђења квалитета (1 оА 4 члана је студент). Они су такађе укьучени у рад научно-образовних савета на факултетима, и у раду комисија за обезбеђење квалитета на факултетима Универзитета. У току реалиације PIQAS пројекта, студенти су имали веома активну улогу и у његовој имплементацији, студијским посетама, панел састанцима, припремању докумената и организацији обука. Присуство студената на шест панела за перодичне евалуације, њихов критички и аналитички приступ Аали су нову димензију самом пројекту. Они су учествовали у анализи извештаја о самовредновању Универзитета и усвајању свих докумената која се тичу обезбеђења квалитета.

Универзитет је током 2019. године усвојио нову Стратегију обезбеђења квалитета и Акциони план за обезбеђење квалитета као резултата PIQAS пројекта и као део пианиране одрзивости PIQAS-а и самог система обезбеђења квалитета на Универзитету. 


\section{2. ПРОЈЕКАТ ЈУГО-ИСТОЧНЕ ЕВРОПЕ ЗА УНАПРЕЪЕЮЕ JЕЗИЧКИХ СТУАИJА (SOUTH EAST EUROPE PROJECT FOR THE ADVANCEMENT OF LANGUAGE STUDIES $)^{2}$}

Универзитет у Приштини са привременим седиштем у Косовској Митровици учествује у свом Аругом Темпус пројекту - SEEPALS координисаним оА стране Универзитета Црне Горе, као партнерска високошколска институција, зајеАно са универзитетима у Перуђи, Марибору, ЕарлангНирнбергу и многобројним универзитетима из региона Западног Балкана. Циь SEEPALS пројекта је био унапређење језичких студија у региону ЗапаАног Балкана фокусирањем на критичко упоређивање Аве академске праксе и регионалне имплементације најбољих студијских модела у Европи за стране језике. Пројекат је хармонизовао студије страних језика у региону, промовисао међуниверзитетску сараАњу, олакшао процес мобилности студента и наставника. Овај Темпус пројекат је такође омогућио размену размичитих идеја и промовисао је регионални академски кредибилитет моАенизацијом постојеће литературе и студија језичке културе на партнерским универзитетима. Мастер студије за превођење и језичко тумачење реализоване су на поједним партнерским универзитетима.

На Универзитету у Приштини са привременим сеАиштем у Косовској Митровици развијен је модул страних језика за посебне намене на Филозофском Факултету у оквиру одсека за стране језике. Овом хибридним курсом унпаређен је раА самог факултета и наставне методологије катеАре за Енглески језик и књижевност. Ванредни курсеви за студенте који су желели Аа унапреде своје језичке вештине и тиме додатно развију своје каријере реализовани су са значајним успехом у оквиру Универзитетског центра за развој каријере и Универзитетског центра за обуке и развој. У оквиру ових центара организовани су базични, елементарни и среАњи нивои курсева пословног енглеског језика за студенте и предузетнике, као и среАњи ниво енглеског језика за медицинаре. Такође је организаван почетни курс француског језика и online курс пословања за студенте, предузетнике и администрацију. На Медицинском факултету основана је нова виртуална Аијагностичка и терапијска учионица чији су полазници добили све неопходне материјале и тестове преко социјалних мрежа. Нова Аигитална учионица је такође отворена на Факултету техничких наука која је опремьена савременим рачунарима и интернетом за све будуће хибридне курсеве у области електронике, рударства, архитектуре, грађевине и електротехничких наука.

SEEPALS је био усклађен са мисијом већег броја Темпус пројеката и снажно је утицао на промоцију регионалне конвергенције ка развојним политикама Европске уније у области високог образовања, а у складу са националним

2 Темпус пројекат број: 511116-TEMPUS-1-2010-1-XM-TEMPUS-JPCR 
и регионалним приоритетима партнерских земаља. Овај пројекат је био усклађен са регионалним приоритетима у области унапређења наставе страних језика у земьама Западног Балкана чијом је аАекватном применом био олакшан приступ ових земаља ка Европској унији премошћавањем језичке баријере. Његовом реализацијом потпомогнут је раА наставника страних језика, преводиоца и тумача, као и студената размичитих старосних група.

У слелећем, четрвтом позиву, за Темпус пројекте у оквиру четврте фазе овог програма, Универзитет Аобија јос Аве нове Аонације за реализацију RINGIDEA и InMusWB пројекта, и учествује у њима као партнерска високошколска институција.

\section{3. РАЗВОЈ ИНФОРМАЦИОНЕ ПИСМЕНОСТИ ЗА ЦЕ ООЖИВОТНО УЧЕЊЕ И ЕКОНОМИЈУ ЗНАҢА У ЗЕМЬАМА ЗАПААНОГ БААКАНА (DEVELOPING INFORMATION LITERACY FOR LONG LIFE LEARNING AND KNOWLEDGE ECONOMY IN WESTERN BALKANS COUNTRIES) ${ }^{3}$}

RINGIDEA је коорАинисан оА стране Института за технологију у $\Lambda$ мерику, у сарадњи са партнерима са Универзитета Мидлсекс, Универзитета у Брашову, Универзитета на Криту и појединим универзитетима у региону Запалног Балкана, а његов циь је био да развије програме информационе писмености за цеможивотно учење и увеАе их у постојеће наставне планове и програме. У исто време овај Темпус пројекат је успоставио иновативне online модуме информационе писмености и хармонизовао их са постојећим програмима у земьама Западног Балкана. RINGIDEA је оснажила капацитете високошколских институција у овим земьама за стратешко планирање и импиементацију програма информационе писмености, а у циьу преношења вештина које би обезбедиме конкурентну и Аинамичку економију засновану на знању у овом неразвијеном региону. Такође овај пројекат је развио адекватне политике информационе писмености, као и оАговарајућа упутства и смернице за њихову примену према специфичним циљевима сваке високошколске институције укјучене у овај пројекат.

ГАавни Аопринос RINGIDEA пројекта на Универзитету у Приштини са привремним сеАиштем у Косовској Митровици оглеАа се у припреми воАича за планирање програма информационе писмености, хармонизацији курикулума за наставу инфромационе писмености и обуци за практичаре информационе писмености, углавном бибмиотекаре. На Универзитету су развијени иновативни online модули за информациону писменост на Факумтету техничких наука и Природно-математичком факултету и извршена је имплементација и промоција програма информационе писмености.

3 Темпус пројекат број: 517117-TEMPUS-1-2011-1- IE-TEMPUS-JHES 
Курс информационе писмености у формалном и неформалном образовању развијен је за међународну метњу школу у Митровици. Шест различитих публикација и смерница на српском језику о информационој писмености је штампано за академску заједницу на северу Косова поА следећим називима: Аефиниција информационе писмености, Смернице за обуку наставника информационе писмености, Интеграција информационе писмености, Пишите исправно, Смернице за планирање програма информационе писмености, Аодатне информације о информационој писмености. Резултати пројекта осигурали су његову одрживост на Ауже стазе.

На нивоу конзорцијума, пројекат је остварио значајна достигнућа кроз публикацију Водич за планирање програма за информациону писменост, као и Наставног плана и програма информационе писмености и Пиана за осигурање квалитета овог програма на свим високошколским институцијама из земања Западног Балкана које су биме учесници овог пројекта.

Након имплементације овог пројекта, Универзитет у Приштини са привременим седиштем у Косовској Митровици је преузео све неопходне мере Aа се програми информационе писмености користе у свим универзитетским библиотекама зарад проналажења адекватних научно-истраживачких података које су умногоме помогли мкадим и искусним истраживачима на Универзитету у спровођењу њихових квалитативних и квантитативних истраживања. Ови програми су свакако допринели, али и значајно олакшали развој научно-истраживачке делатности на Универзитету и увећали број научних радова објављених у домаћим и страним часописима од стране професора и студената. Универзитет је у циљу промоције самог RINGIDEA пројекта организовао Аане библиотеке гАе су резултати овог Темпус пројекта промовисани, а у исто време је постао чиан мреже за информациону писменост ЗапаАног Балкана која преАставља Аодатану вредност овог пројекта и која је наставика са радом и након завршетка овог пројекта.

4. УВОЪЕЊЕ ИНТЕРАИСЦИПАИНАРНОСТИУ МУЗИЧКЕ СТУАИЈЕ УЗАПААНОМ БАЛКАНУ У СКАААУ СА ЕВРОПСКОМ ПЕРСПЕКТИВОМ (INTRODUCING INTERDISCIPLINARY IN MUSIC STUDIES IN THE WESTERN BALKANS IN LINE WITH EUROPEAN PERSPECTIVE) $)^{4}$

Свеобухватни циь InMusWB пројекта је био реорганизација музичког образовања у земьама Западног Балкана у складу са тренутним европским музичким трендовима. Овај циь је остварен захваьујући реализацији слеАећих посебних циљева пројекта:

1. модернизација курикулума за први и Аруги циклус студија,

4 Темпус пројекат број: 517098-TEMPUS-1-2011-1-RS-TEMPUS-JPCR 
2. развој и упознавање са новим модерним и флексибилним интердисциплинарним стуАијским програмима на сва три студијска циклуса,

3. развој и имплементација регионалне континуиране едукације са сертификованим курсевима целожиовотног уцења.

Овај Темпус пројекат је био координисан оА стране Универзитета уметности, Факултета музичких уметности у БеограАу, у сараАњи са Краљевском академијом за музику у Стокхолму, Академијом музике и театра из Аитваније, Музичком акаАемијом из Һубьане, Јаначек академијом из Брна, $\mathrm{Y}_{\mathrm{A}}$ ружењем европских конзерваторијума, Аустријском академијом науке, и одређеним универзитетима из региона Западног Балкана.

У оквиру InMusWB пројекта, нови студијски програми виоле и виолончела на основним и Мастер студијама су уведени на Факултету уметности Универзитета у Приштини са привременим сеАиштем у Косовској Митровици. Оба студијска програма су осмишьена у складу са европским перспективама за високо образовање у области музичког образовања и у скмаАу са Болоњским принципима. Наставна методологија, исходи учења, одређен број ЕСПБ-а, су врко прецизно и транспарентно уведени узимајући у обзир студенску евалуацију и потребе будућих Аипломираних студената за запољшењем након завршетка студија у нижим и среАњим школама. Због тога оба студијска програма имају за циь поред унапређења компетенција извођачке уметности и унапређење пеАагошких вештина. Студијски програми виоле и виолончела су усвојени оА стране одговарајучих структура самог универзитета и Националне комисије за акредитацију и осигурања квалитета. Факултет уметности је такође оА самог почетка пројекта постепено увео некомицину изборних курсева у студијске програме основних и мастер стуАија који поАразумевају употребу Аигиталне технологије у музици и пеАагогији музике.

Ава професора која нису била упошьена на Факултету уметности су ангажована за сваки појединачни студијски програм виоле и виолончела и одређен број студената је уписан према броју које је одобрило Министарство за образовање, културу и технолошки развој. На овај начин одрживост пројекта је осигурана на Ауже стазе, а Универзитет је реализацијом InMusWB пројекта добио Ава нова акредитована студијска програма и по први пут стекао услов Аа се оснује оркестар Универзитета оА каА Универзитет функционише на северу Косова.

На пољу модернизације InMusWB пројекат је Аопринео Аа студенти Факултета уметности и све будуће генерације ових студената усвајају нова знања путем најновијих наставних методологија и регуларним коришћењем компјутера и специјализованих софтвера. На овај начин пројекат је утицао не само на Музички оАсек Факултета уметности него и све будуће стуАенте и ученике студената који ће усвојити нова знања преко најновијих наставник метода. 
У оквиру InMusWB пројекта, Факултет уметности Аобио је и оАређен библиотечки фонА и оАговарајућу опрему за реализацију овог пројекта ( ааптопови, Imacs, штампачи, Аигитални снимачи) укьучујучи и 3 пианина, жице за виолу и виолончело, држаче нота, набавьену у скиаду са свим законима и прописима које прописује тендерска процедура. Сва добијена опрема користи се и даље од стране академског и административног особња факултета и студената.

ОАређен број публикација је такође штампан који је био неопходан за реализацију оба студијска програма. То су углавном била монографска изАања наставника факултета, која могу Аа се користе и као наставни материјами и приручници и брошуре за курсеве целоживотног учења.

У оквиру овог пројекта остварена је и јеАна оА првих студентских мобилнсоти на Јаначек Академији у Брну, гАе је јеАан студент Факултета уметности био на усавршавању. Професори са Универзитета у ьубњани, Јаначек Академије и Факултета музичке уметности у Београду, су посетили Универзитет и Факултет уметности у оквиру InMusWB пројекта и том приликом су одржали свој мастерклас. Такође Ава професора Факултета уметности су имали прилику Аа посете Крањевску академију музике у Стокхолму и Јаначек академију музике и извођачке уметности у Брну.

Студенти виоле и виолончела су остварили и значајну концертну праксу у оквиру својих регуларних активности, али и оних ван-наставних укьучујуци учешће на информативним данима Темпус програма одржаних у свечаној сали Ректората. Они су такође остварили значајне успехе на мокалним и регионалним такмичењима.

У шестом позиву за Темпус пројекте у оквиру четврте фазе овог програма, Универзитет је Аобио грант за 3 нова пројекта, оА којих је јеАан коорАинирао (BLATT), а у остала Ава (RESARCH і ENERGY) је учествовао као партнерска високошколска институција.

\section{5. ХИБРИАНО УЧЕЊЕ: УНАПРЕЪЕНА ОБУКА ЗА НАСТАВНИКЕ (BLENDED LEARNING: ADVANCED TEACHER TRAINING) ${ }^{5}$}

Свеобухватни циљ BLATT пројекта је био системска импмементација хибриАног учења на Универзитету у складу са Болоњским принципима, а специфични циљеви овог пројекта обухватили су:

1. побољшање и унапређење наставничке и студентске праксе коришћењем пеАагошких иновативно-образовних технологија,

2. промоција нове наставне методологије гАе је студент у центру процеса учења,

5 Темпус пројекат број: 530266-TEMPUS-1-2012-1-XK- TEMPUS-JPCR 
3. упознавање са континуираним и формативним проценама прогреса студената,

4. суочавање и превазилажење изазова дисперзног универзитета путем Аетаљног мониторинга и континуираности у учењу.

Овај пројекат је спроведен у сарадњи са Универзитетом у Марибору, $\Lambda$ инеас Универзитетом, Универзитетом у Болоњи и пројектном консултантском кућом из Саццбурга (PROJEKT kompetenz). Након увођења троцикличног система студирања процес модернизације високог образовања на Универзитету у Приштини са привременим сеАиштем у Косовској Митровици наставьен је са BLATT пројектом који је иновирао методологију учења и увео циьно орјентисано учење, Аа би обезбедио ефикасније студијске програме и образовање које је базирано на потребама тржишта рада. Овај Темпус пројекат је помогао Универзитету на путу ка европском простору за високо образовање увођењем електронског учења и праксе. Пројекат је произвео Аобре резуктате у побољшању постојећих метода за хибридно учење на Универзитету у складу са европским образовним стандардима за хибридно учење.

На почетку спровођења овог пројекта већина наставника и студената нису били укьучени у учење на Ааљину и хибридно учење већ су се углавном ослањали на старе наставне методе и технике. Ситуација се знатно променила оА тада са увођењем BLATT пројекта јер су сви наставници и студенти били укьучени у овај пројекат са жеьом Аа науче више о хибриАним методама учења, Аа би стекли јеАно ново искуство и Аа би исто применили у свакодневном раду. На националном нивоу, овај пројекат је био подржан оА стране Национакног савета за високо образовање и Комисије за акреАитацију и осигурање квалитета која поставља стандарде за акредитацију емектронских курсева.

Оцењено је у току пројекта Аа је наставно особье Универзитета установияо одређен број обавезних и изборних предмета који су Аобро осмишьени и који су усвојили овај нов приступ у учењу. Теоретско знање и наставна методологија су прилагођени хибридним постулатима и усвојен је нов приступ ка студентима који су сада у центру процеса учења. Студенти су стекли нове вештине које ће им омогућити Аа макше пронађу посао у доба интензивне употребе информатичких и комуникационих технологија.

BLATT курсеви промовишу групни раА и интеракцију између студената уз помоћ одговарајућих задатака. Они такође укьучују одређене могичке вештине у разумевању и евалуацији студентских задатака гАе наставници само наводе студента са одређеним инструкцијама ка решењу појеАиних задатака.

У оквиру BLATT пројекта 700 студената је похађамо оАређен број хибриАних курсева и они су научени Аа користе ове савремене приступе у решавању својих професионалних задатака. На овај начин циь BLATT пројекта Аа обухвати сто већи број студената је остварен на различитим 
факултетима универзитета. Студенти су усавршили своје вештине и велики Аео студентског тека је имао користи у припремању за одговарајући посао стицањем нових вештина у оквиру Б $\Lambda$ АТТ ван наставних активности.

Имплементација пројектних активности BLATT-a је оА самог почетка била подржана оА стране партнера из земаља Европске уније. Подршка оА стране Универзитета у Марибору и Аинеас Универзитета који су понудили Adobe Connect виртуелну собу за састанке омогућила је све зајеАничке састанке пројектног конзорцијума. Партнери из Европске уније су понудили и експертизу која се тицала свих аспекта емектронског учења и истоимене методологије која је усвојена путем размичитих радионица. Већина курсева је бика оАржана преко АМРЕС и БААЕН мреже која поАржава хибриндо учење на целом Балкану.

\section{6. РЕСТРУКТУИРАҢЕ СТУАИЈСКОГ ПРОГРАМА АРХИТЕКТУРЕ} КА ИНТЕГРИСАНОМ МАСТЕРУ АУГОГ ЦИКАУСА У СКАААУ СА СТАНААРАИМА ЕВРОПСКЕ УНИJЕ (RESTRUСTURING OF STUDY PROGRAMME IN ARCHITECTURE TO LONG-CYCLE INTEGRATED MASTER IN LINE WITH EU STANDARDS $)^{6}$

Свеобухватни циљ RESARCH пројекта је био Аа унапреди образовање архитеката кроз развој и имплементацију интегрисаног мастер студијског програма према уреАби Европске комисије за акредитацију и стручну квамификацију у области архитектуре као регулисане професије. Сходно томе специфични циљеви овог пројекта су бими следећи:

- реструктуирање студијског програма архитектуре у интегрисани мастер студијски програм који је прилагођен уреАби 2005/36/ЕЦ,

- развој постојећег студијског програма на начин који омогућава стицање права на националну акредитацију и међународно признање квалитета у складу са критеријумима националне акредитационе комисије и релевантних међународних институција,

- Аоступност јеАинственог студијског програма архитектуре на националном нивоу као и реализација одређене врсте обука, које би отвориле нове могућности за мобимност и сарадњу са академским и административним особьем, и студентима у Европи, у складу са стандардима Европског УАружења за архитектонско образовање,

- обезбеђење одговарајућих диплома, сертификата и других потврда које се тичу формалног образовања,

- обезбеђење одговарајуће опреме и неопходног наставног материјала за реализацију новог студијског програма и усвајање нових наставних метода,

6 Темпус пројекат број: 530440-TEMPUS-1-2012-1-XM- TEMPUS-JPCR 
- пренос и усвајање нових знања и експертизе од академског и неакаАемског универзитетског особьа са партнерских високошколских институција у Европској унији.

Реструктуирање студијског програма архитектуре и његово усаглашавање са националним и европским уредбама у овој научној области имало је највећи значај за цемокупан RESARCH пројекат. ГАавни резултат пројекта је свакако акредитација новог студијског програма у архитектури који је усаглашен са европским уреАбама за регулисане професије. Нова опрема која је набављена из буџета овог пројекта као и оАређен бибмиотечки фонА Аодатно су омакшали реализацију RESARCH пројекта.

Имплементација новог стуАијског програма започела је 1. октобра 2014. године. ПореА националне акредитације, Универзитет у Приштини са привременим сеАиштем у Косовској Митровици - Факултет техничких наука, Аобио је чианство у Европском удружењу архитектонског образовања што је највише међународно признање у овој области.

Прикиком развијања новог курикукума водимо се рачуна о томе Аа буде ускиађен са европским стандардима тако Аа ће студенти који буду завршили нови програм мастер студија моћи Аа несметано траже посао на европском тржишту рада. Пре него што Аипломирају они ће морати Аа заврше Аве врсте пракси: на градилишту и у оквиру архитектонског бироа.

У оквиру овог Темпус пројекта остварена је и сарадња између одсека за архитектуру Факултета техничких наука са неакадемским сектором. Прва заједничка активност са општином Грачаница започела је новембра 2014. године каАа су стуАенти и професори посетили ову општину и имахи прилику аа се сретну са градоначелником, преАставницима општинског сектора за просторно планирање и туристичком организацијом Грачаница, Аа би развили Ава нова архитектонска пројекта која су се тицала отварање нове туристичке канцемарије и новог изможбеног павиьона. Остварена је и сарадње са Аомом културе у Грачаници у јануару 2015. године. У фебруару исте године, у уметничкој гамерији у Грачаници отворена је изможба најбољих радова студената архитектуре, а Аом културе је тим поводом штампао каталог.

Студенти Факултета Техничких наука су у оквиру RESARCH пројекта остварили право на студентску мобилности. Три студента овог факултета учествовама су на метњој шкоми Универзитета у Риги на обукама из урбанизма, архитектуре и Аизајна, која је трајала Аве неАеье. Циь ових обука је био Аа обучи младе архитекте, урбанисте и Аизајнере за будуће професионалне заАатке, али и Аа развије оАговорност коју ова професија захтева оА њих у будућем раду. Стуленти су успешно завршили ову обуку и вратили се на свој матични факултет са Аипломом оА 3 ЕСПБ-а, уручене оА стране Техничког Универзитета у Риги, Факултета за архитекуту. 
На крају, пројекат RESARCH изнедрио је јако плодну сарадњу међу члановима конзорцијума (Универзитет Црне Горе, Технички универзитет у Риги, Универзитет у Бубьани, Технолошко-образовни институт у Атини), што је током следећих година допринело развоју и имплементацији нових међународних Еразмус+ пројеката у области високог образовања.

\section{7. РАЗВОЈ МРЕЖЕ ОБУКА ЗА УНАПРЕЂЕЊЕ ОБРАЗОВАҢА

 OF TRAINING NETWORK FOR IMPROVING EDUCATION IN ENERGY EFFICIENCY) ${ }^{7}$}

Темпус пројекат ENERGY је координисан оА стране Техничког универзитета у Риги, а у сарадњи са универзитетима из Талина, Вилниуса, Аублина, Косзалина, Брижа, Галатија, Бакуа, Минска, са циљем унапређења и реформе високог образовања у области енергетске ефикасности, очувања енергије и коришћења обновьивих извора енергије. Сходно овом свеобухватном циьу пројекат је имао следеће подциьеве:

- развој и побољшање одговарајућих курикулума у области унапређења енергетске ефикасности, очувања енергије, енергетски ефикасних материја$\Lambda а$, коришћења обновьивих извора енергије,

- развој и унапређење рада одговарајућих кабараторија у овим спечифицним научним областима,

- развој одређених наставних курсева у овим савременим наставним обмастима,

- развој наставног материјала за одређени број наставних курсева,

- набавка нове опреме за мабараторије,

- креирање електронских библиотека које би саАржале унапређен и моАернизован наставни материјал.

Све партнерске и програмске земье које су биме укьућене у овај пројекат суочавале су се са истим проблемом у недовољном броју размичитих енергетских ресурса. Пројекат је пре свега решио зајеАнички проблем који се тицао неразвијене инфраструктуре потребне за интензивно коришћење технологија које се користе у очувању енергије, посебно обновьивих извора енергије. Овај проблем је решен повећањем броја експерата у овој области и стварањем одговарајућих услова за профитабилност коришћења технологија за очување енергије и обновьивих извора енергије.

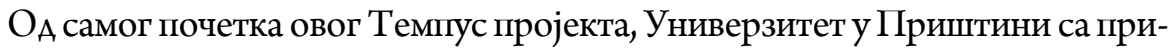
временим седиштем у Косовској Митровици, посебно Факултет техничких

7 Темпус пројекат број: 530379-TEMPUS-1-2012-1-LV- TEMPUS-JPCR 
наука, радио је на имплементацији пројекта имајући у виду профих експерата који би заАовољили потребе тржишта раАа. Овај циљ је остварен кроз развој новог курикулума и акредитацију нових курсева. ГАавни корисници пројекта су наставници и студенти овог факултета.

ENERGY пројекат је узео у обзир енергетска питања из развојних стратегија партнерских земьа и у склаАу је са националним приоритетима који се тичу инжињерства и инжињерске трговине у свим партнерским земьама укьученим у овај пројекат. Пројектни тим ENERGY пројекта уврстио је најновија научна сазнања у оквиру својих наставних планова и програма са преАвиђеним комплементарним ефектима коришћења савремене опреме у новим мабараторијама.

ГАавни Аопринос партнерских високошколских институција је у развоју наставног материјала у форми књига које су у скмаду са најновијим европским стандардима у Аатим научним областима. Пројекат је увео нове модернизоване курикукуме са новим акредитованим курсевима, новим књигама и новом мабараторијском опремом, што је Аопринело унапређењу наставе енергетске ефкасности.

Са реализацијом овог пројекта направљен је инцијамни корак у реструктуирању акредитованих студијских програма и по први пут је ово урађено на основу примера најбове праксе и разменом искуства са универзитетима из напреАних програмских земаља. Ово искуство је пример који може Аа послужи у реструктуирању осталих студијских програма. Нови курсеви ће омогућити боље прикике за запошьење Аипломираних студената јер они поседују одговарајуће знање, компетенције и вештине, које ће допринети реАукцији коришћења електричне енергије и промовисању енергетске ефикасности у инаустријској употреби.

\section{ЗАКЬУЧАК}

На основу овог истраживања о развоју и реализацији Темпус програма на Универзитету у Приштини са привременим сеАиштем у Косовској Митровици, утврђено је, Аа је Универзитет захваљујући великом ентузијазму и развоју постојећих капацитета постао мидер у импмементацији овог програма на северу Косова. Темпус је додатно допринео унапређењу већ започетих процеса реформе и модернизације Универзитета преАвиђених Болоњском Аекларацијом.

Спровођењем 7 Темпус пројеката Универзитет је сопственим примером показао како се стратегија интернационализације универзитета спроводи на најадекватнији начин и као такав, постао не само пример за остаме високошколске институције на северу Косова, већ је стао раме уз раме 
са осталим универзитетима у Србији који имају знатно Ауже искуство у спровођењу овог програма.

Спровођење европских стандарда за осигурање квалитета на нивоу Универзитета, нови студијски прогами у обкасти архитектуре и енергетске ефикасности, унапређење студија Енглеског језика, информатичке писмености, интерАисциплинарности музичких стуАија и хибриндог учења, само су неки оА резултата ових пројеката.

Универзитет је такође остварио велики број студијских посета академског и аАминистративног особьа и студената Универзитета, на еминентним партнерским универзитетима у земьама Европске уније који су били део Темпус пројектних конзорцијума. На овај начин Универзитет је додатно оснажио већ постојеће циљеве интернационализације Универзитета, разменивши искуства и експертизе са партнерима из ЕУ и започевши са попумаризацијом мобимности која ће остварити свој пуни потенцијал са развојем Еразмус+ пројеката међународне кредитне мобимности.

Универзитета у Приштини са привременим сеАиштем у Косовској Митровици у областима које су биме обухваћене Темпус пројектима, промовишући процес интернационализације као важан алат за константан раст и прогрес, и следећи примере најбоље праксе европских земаља.

Са новим Еразмус+ програмом Европске уније за образовање, омладину и спорт, Универзитет је наставио са већ започетом добром праксом и стекао вемики број нових пројеката који су Аодатно подржали развој Универзитета и његову тежњу ка универзалним европским вреАностима у обкасти високог образовања.

На крају овог рада, аутори се захваьују Канцемарији за међународну сарадњу и свим пројектним менаџерима Темпус пројеката на Универзитету у Приштини са привременим сеАиштем у Косовској Митровици на свим преАложеним сугестијама које су биле оА вемике помоћи Аа се резултати ових пројеката прикажу на најобјективније начин прикиком писања овог рада.

\section{АИТЕРАТУРА}

Божовић, Аазић 2015: Божовић, Ј. и Аазић, Г. Реформа и модернизација система високог образовања у изабраним земљама Западног Балкана / Reform and modernization of the higher education systems in the chosen western Balkan Countries. Национацна конференција са међународним учешћем: Реинжињеринг пословних процеса у

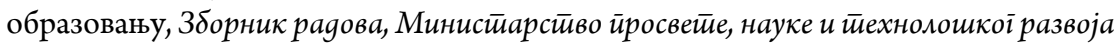
Рейублике Србије: Чачак, 22-27. Септембар 2015, стр. 407-416. Аоступно на интернет аАреси:http://www.ftn.kg.ac.rs/konferencije/rppo15/

Весковић, Маринковић Недучин, Симић, Цвејић Познић 2013: Весковић Мирослав, Маринковић Недучин Радмика, Симић Микан, Цвејић Познић Јемена: Темӣус иројекй ГОМЕС-Реформа уйрављања и руковођења у високом образовању у Србији. Универзитет у Новом Саду, Нови СаА 
Вујачић, Ђорђевић, Ковачевић, Шундерић 2013: Вујачић Илија, Ђорђевић Снежана, Ковачевић Маја, Шундерић Ивана: Country Report: Serbia-Overview of Higher Education and Research Systems in the Western Balkans. Норвешки савет за истраживање, БеограА, 2013

Аукиандијев, Аукић 2010: Аукиандијев Стефан анА Аукић Софија: Tempus programme and reform of higher education in Serbia and Montenegro. ФонАација Темпус, БеограА

Ђурашевиц, Вујаков, Фикиповић-Ожеговић, Банковић, Станојмовић, Жувека, Арагаш, Шкаљац 2015: Ђурашевиц Синиша, Вујаков Ивана, Фикиповић-Ожеговић Марија, Банковић Марко, Станојмовић Бојан, Жувека Ирена, Арагаш Јемена, Шкаљац Милена: Мобилности у високом образовању-Воgич за високошколске инстиийуције. Фондација Темпус, БеограА

EACEA 2012: Overview of the Higher Education Systems in the Tempus Partner Countries: Western Balkans, EACEA, Brussels

EU and EFTA/EEA 2015: Study on Higher Education provision and labour market opportunities in the Western Balkan - Serbia Country Report, European Commission, Brussels

European Commission/EACEA/Eurydice: Modernization of the Higher Education in Europe, European Commission/EACEA/Eurydice, Brussels, 2014.

European Commission 2010: State of Play of the Bologna process in the Tempus Countries (2009 2010), European Commission, Luxembourg

European Commisssion 2016: From University to Employement-Higher Education Provision and Labour Market Needs in Serbia, European Commission, Brussels

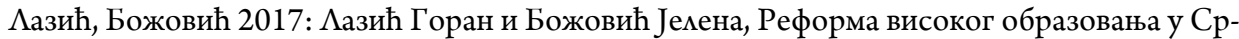
бији-Социјална димензија и критички осврт, Зборник раgова Изазови оgрживоі

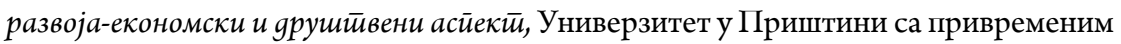
седиштем у Косовској Митровици-Економски факултет, Косовска Митровица

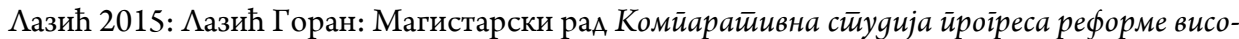
кої образовања у земьама Зайаgної Балкана. Факултет Политичких Наука, БеограА

Филиповић Ожеговић, Аукић, Шкаљац, Банковић, Жувела, Стојановић, Бабић 2015: Филиповић Ожеговић Марија, Аукић Софија, Шкаљац Милена, Банковић Марко, Жувема Ирена, Стојановић Нина, Бабић Ивана: Аванаест̄ іолина йроірама Евройске уније из обласиии образовања у Рейублиии Србији, ФонАација Темпус, БеограА

Филиповић Ожеговић, Аукић, Шкаљац, Банковић, Жувела, Стојановић, Бабић 2015: Фикиповић-Ожеговић Марија, Аукић Софија, Шкаљац Микена, Банковић Марко, Жувема Ирена, Стојановић Нина, Бабић Ивана: Учешће Србије у йроіраму Еразмус+. Фонација Темпус, БеограА

Фондација Темпус 2015: Фонgачија Темӣус: Мобинносӣ у високом образовану-Водич за високошколске инсииийуције. Фонаација Темпус, БеограА 
Goran B. LAZIĆ

Igor N. ĐURIĆ

\section{DEVELOPMENT OF TEMPUS PROGRAMME AT THE UNIVERSITY \\ OF PRIŠTINA SETTLED IN KOSOVOSKA MITROVICA}

\section{SUMMARY}

Higher Education reform and modernization processes in Serbia were initiated by the overall 'Europe of knowledge' project, which encompassed Bologna and Lisbon declarations aiming to enroll Western Balkan countries into unique European Higher Education Area. By the adoption of the Law on Higher Education in 2005, these processes obtained their legal ground in Serbia and regulated implementation of the principles of both declarations, while Tempus (Trans-European Mobility Programme for University Studies) as the European Union programme for reform and modernization of Higher Education additionally supported internationalization of Higher Education Institutions in Serbia and harmonization of their curricula with highest European educational standards. This essay gives an overview on development of Tempus programme at the University Pristina temporarily settled in Kosovska Mitrovica since 2009, when the university for the first time applied for this kind of donation until its official closure and completion of implementation of all its projects where university was involved.

Key words: Tempus, reform, modernization, Higher Education.

РаА је преАат 29. маја. 2020. године, а након мишьења рецензената, оАлуком оАговорног уредника Башӣине, одобрен за штампу. 